\section{ECONOMICS}

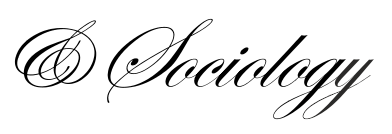

Kačerauskas, T. (2018). Indices of Creative Economy: Critique of R. Florida's Creativity Indices. Economics and Sociology, 11(4), 280-288. doi:10.14254/2071789X.2018/11-4/18

\title{
INDICES OF CREATIVE ECONOMY: CRITIQUE OF R. FLORIDA'S CREATIVITY INDICES
}

\author{
Tomas Kačerauskas, \\ Vilnius Gediminas Technical \\ University, \\ Faculty of Creative Industries, \\ Vilnius, Lithuania \\ E-mail: tomas.kacerauskas@vgtu.lt
}

Received: January, 2018

1st Revision: March, 2018

Accepted: June, 2018

DOI: $10.14254 / 2071-$

789X.2018/11-4/18

JEL Classification: $\mathrm{O} 10$

\begin{abstract}
This paper analyzes R. Florida's creativity indices as related to creative economy. The argument consists of six specific criticisms. 1. Counting the Gay Index is problematic because "gay" is a cultural, social and ethical category, not a physical one. 2. The Talent Index expresses something fundamentally contradictory to talent, namely, an orientation towards an average consumer's taste. As the Talent Index rises, the actual talent of a society decreases and loses value. As university education becomes more and more attractive, it becomes more easily attainable, and, hence, becomes devalued and, thus, less attractive. Instead of contradicting one another, social and creative capitals supplement each other. 4. There is a saturation point to immigration, so that increasing immigration past this point no longer increases creativity. 5. The Melting Pot Index should be extended by accounting for second and third generations of immigrants. 6. Creativity of a society is nourished not only by its variety but also by its identity, which is inseparable from traditions that have been handed-down over generations.
\end{abstract}

Keywords: creative economy, creative society, creative capital, social capital, Gay Index, Talent Index, Melting Pot Index.

\section{Introduction}

Scholars try to explain the nature of creativity by appealing to historical (Adomaityte et al., 2018) and contemporary (Barevičiūtè, 2014) societies and by analysing their cultural context (Liubinienė \& Thunqvist, 2015) and its various manifestations (Murphy \& Schlaerth, 2015; Pruskus, 2015; Rabazauskaite, 2015).

In the past several decades, scholars have developed creativity research indicators in psychology, philosophy, sociology, management, economics, technology, and regional studies. Psychologists often utilize the Torrance Test (Torrance, 1966), Psychological Indices (Cherry \& Latulipe, 2014; Furst et al., 2012; Runco, 2004), (In)tolerance for Uncertainty (Kornilova \& Kornilov, 2012), Index of Imagination (Liang et al., 2013), Indicators of Originality and Appropriation (Runco, 2005), Indicator of Intelligence (Squalli \& Wilson, 2014), Multiple Index of Creativity (Reiter-Palmon et al., 2009), Integrated Index of Socialization, Externalization, Combination, Internalization (Chang et al., 2014), and the General Thematic Area factors of Creativity (Kaufman, 2009). 
Philosophy as a meta-science deals with the limitations of empirical research in creativity, as well as with the negative aspects of creativity in general (Rank, 1989; Arndt, 1999). Within philosophy, aesthetics looks for possible criteria for creativity in art (Furst et al., 2012; Juzefovič, 2015; Vabalaite, 2017; Zolfani et al., 2017; Piskunova et al., 2018; Manta, 2018). Beside this, critical thinking has been treated as an aspect of creativity (Yi, 2018). According to some scholars, ecological (Paek, 2018) and ethical (Valatka, 2016) issues are inseparable from the creativity.

Sociology constructs indices of creative climate (social environment) (Hunter, 2007) and quantitative models of creativity (Soler, 2007; Carroll, 2009; Cherry, \& Latulipe, 2014; Weinstein et al., 2014). Pedagogy establishes predictors of creativity in education (Batey, 2010; Juzefovic, 2015; Yasmin \& Sohail, 2018).

Management theories treat creativity as an area of intellectual capital (Bounfour, 2003; Kačerauskas, 2016). Economics define criteria for innovative products (Chang et al., 2014; Černevičiūtè, \& Strazdas, 2014) and studies aspects of creative economy (Power, \& Scott, 2004; Scott, 2000; Weinstein, 2000). In presenting creative economy as such, J. Howkins (2007) and Martinaitytè, Kregždaitè (2015) review different branches of creative industries and their place in the economy.

Technological sciences explore different factors of technological innovation (AlSudairi, Bakry, 2014; Fu, 2008), the index of patents (Al-Sudairi \& Bakry, 2014), and digital tools in creativity (Caroll, 2009; Cherry, Latulipe, 2014; Weinstein et al., 2014). Regional studies consider different indices of regional development (Florida, \& Tinagli, 2004; Gong, 2013; Hong Kong, 2004; Shanghai Creative Industries Center, 2006; Cetindamar, \& Gunsel, 2012; Lee et al., 2004; Weinstein, 2000; Kraetke, 2010) including the factors which determine creative cities (Florida, 2005; Cetindamar, Gunsel, 2012; Scott, 2000, Krätke, 2003; Cooke, Lazzeretti, 2008; Aglinskas, 2014; Lavrinec, 2014b; Staniulyte, 2017).

R. Florida $(2002,2012)$ raises the question of how to characterize the creative class, the main agent of creative society, in terms of indices. The Bohemian, High Tech, Gay, Talent and Melting Pot Indices which he defines could be treated as the qualitative indices of the creative society. Furthermore, he defines two integrative creativity indices which we call the Major Index and Minor Index according to their greater or lesser scope. While the Minor Integrative Index covers only the Bohemian, Melting pot, and Gay Indices, the Major Integrative Index covers all the mentioned six indices. However, these indices raise more questions than they provide answers. Why has creative society been represented by namely these and not other indices? How can these indices be measured when the social groups represented by them are not definable in principle? Who could be attributed to these groups represented by creativity indices? Do not some of the abovementioned indices measure social uniformity instead of creativity? Does the integration of indices mean that R. Florida claims to have accounted for all possible creative indices? Who champions these indices - the creative society's theorists or politicians? Does the development of creative society presuppose modified and entirely new indices?

The paper deals with these and other questions related to the creativity indices proposed by R. Florida which could also be considered as the qualitative indices of creative economy. First, we will analyse the Gay Index, then the Talent and Melting Pot Indices, and finally, the Integrative Indices combining the previous ones.

\section{Gay Index}

The Gay Index is the percentage of homosexual couples in a region compared with the national index. R. Florida (2002, 2012) does not state that gays are especially creative individuals who improve the statistics of a creative economy. R. Florida distances (2002, 
2005, 2012) himself from this sexual racism which is still found in postmodern society. Indeed, the fact that a society is postmodern and post-industrial does not mean that it is less superstitious ${ }^{1}$.

The changing of identities is also characteristic of gays. If gender is a cultural (rather than physical) category ${ }^{2}$, sexual orientation is such even more so. In other words, not so much inborn inclination as certain cultural and social roles form the identity of a (non) gay. This can be illustrated by examples when after having been married for decades a man unexpectedly "understands" that he is gay. He could be both pushed into the region of gayness by his wife and attracted by other agents. Beside this, every gay is a woman in a certain sense to the extent that he finds other men attractive. This could be said not only about a passive partner. Every gay is more creative than a nongay in the sense that he creates another identity despite the attributes of his biological gender. As result, the notion of gays' special creativity has been supported not only by pre-modern and modern superstitions but also by postmodern attitudes that gender and sexuality are cultural categories that change along with changes in the environment for individual identity.

It is worth noting that changes in an individual and their environment are not synchronic, but rather diachronic, especially speaking about the creative individuals who seek to stand out in their environment. That is why "successful" marital life or an especially puritan society can push an individual to become a gay. Puritanism is an attribute of social capital that tends to vanish in postmodern society. In this way, an environment very contrary to modern industrial society forms; now gays seek to stand out above this environment by appealing to traditional values. If heterosexuals are supporters of free partnership without marital ties, then gays are the biggest fighters for marriage in the society of unmarried people who constitute postmodern creative society. As a result, social capital is very important in speaking about gays in that they are creating their identity. This is another argument against R. Florida's statement that social capital is to be replaced by creative capital. Thus these two capitals do not exclude each other but rather supplement each other by changing their roles and expectations in a motley creative society.

Another aspect important in trying to make sense of the Gay Index is to appreciate identity. Identity is created upon moving towards a chosen goal that changes as it is reached or not and as the outcomes are evaluated in one's social environment. If an individual does not recognize that they have created a certain identity, it means they are uncertain as to the social role they have taken. Be that as it may, identity is a category of relationship with one's social environment. Consequently, identity is also an ethical category. Gay identity is no exception.

All of these considerations lead to the conclusion that it is impossible to count gays. It is impossible not only because of the fact that some such individuals are not self-defined as gays. The problem of bisexuality follows also from the fact that "gay" first of all is a cultural, social and ethical category, but not a physical one. Bisexualities emerge in social environments that overlap with each other and where inclinations and orientations are changing. This overlapping and changing are the attributes of a creative society: creativity is nourished by migrating ideas that fill up with unique content after being in different identity regions. Although it is impossible to measure gayness, it does indirectly reflect the diversity of society and nourishes its creativity. Nevertheless, R. Florida's (2002, 2005, 2012) optimism concerning this "empirical" index is without basis. In this case, the empirical nature (observability) of a phenomenon is only one form of its manifestation: by trying to demarcate it from other (unobservable) aspects it loses its empirical content.

\footnotetext{
${ }^{1}$ Remember H.-G. Gadamer (1975): the biggest superstition is the belief that the superstitions can be removed.

2 According to feminists of different generations, such as J. Butler (1990) and L. Irrigeray (1977).
} 


\section{Talent and Melting Pot Indices}

The Talent Index is the percentage of persons with bachelor's and higher degrees within a region. The biggest problem with this index is its name. A question arises as follows: if you are able to graduate from a college with at least a bachelor's degree, then are you already talented enough? A good example is Lithuania, which is one of the leaders in Europe according to this index. However, the Talent Index cannot be a direct index of talent or creativity because it expresses rather the availability or inexpensiveness of college and university education. That is why it indicates not so much an intentional policy of creativity as a national social policy of keeping young people out of an overfilled work market. It also shows the high status of university education (i.e. a certain tradition) in a society, the members of which seek this prestigious education at any cost. We face a paradox here: as university education becomes more and more attractive, it becomes more easily attainable, and hence becomes devalued, and thus less attractive. In this way, we face an inflation of university education, ipso facto an inflation of talents that has been exacerbated by competition amongst universities and colleges. As result, studies have grown less expensive.

Aside from this, the struggle for higher ratings in the eyes of consumers leads not so much to original works (i.e. study programmes) that would form the taste of consumers as to established works that pander to it. We have a similar situation in the media. If so, the Talent Index expresses something fundamentally contradictory to talent, that is, an orientation towards the average consumer's taste. Each index considered serves a policy of increasing it so as to increase the creativity of society. We face a contradiction in the case of the Talent Index: as the Talent Index rises, the actual talent of a society decreases and loses value. It is impossible to measure talent which is unique. After becoming measurable i.e. mass, it loses its significance. In summary, this index is easily measurable but is dubious as a creativity index.

The Melting Pot Index is the percentage of people who were born abroad or in another region. R. Florida (2002, 2012) argues his idea as follows: the more immigrants there are from other countries, the more tolerant a region's society is, consequently, the more creative it is. Furthermore, immigrants import creative ideas which provide additional creative impulses after interacting with other ideas developed in a region. Nevertheless, a high Melting Pot Index is a threat to social capital (Putnam 2000, Portes 1998). If the wasting of social capital contributes to creativity, than a high Melting Pot Index does, too. This idea follows from R. Florida's $(2002,2012)$ considerations. Nevertheless, my thesis is as follows: instead of contradicting one another, social and creative capital supplement each other. If so, the significance of the Melting Pot Index for creativity is doubtful. A high Melting Pot Index indicates incommensurable heritages rather than the exchange of creative ideas. In other words, the more immigrants there are from a certain region, the more closed communication there is between them: a city in a city has been created. First of all, the Melting Pot Index shows the attractiveness of a state to immigrants and the low threshold for immigration. It remains an open question whether a society attractive to immigrants with a low threshold for immigration is also creative. There is a saturation point to immigration, such that increasing immigration past this point no longer increases creativity.

There is a need for a deliberate immigration policy both to balance emigration and to promote a creative environment. This can be illustrated by cases from history. In Lithuania, the first who understood the significance of immigration was the great duke Gediminas, who invited craftsmen and merchants from Western Europe in the beginning of the $14^{\text {th }}$ century. His policy proved very successful: not only did it invigorate the crafts and trade, but also the general economic climate, providing new spaces for creative expression. This policy of openness to immigrants was continued successfully by Gediminas's grandson Vytautas the 
Great who established colonies of Karaims and Tatars and granted privileges to Lithuania's Jews $^{3}$.

The Melting Pot Index can be extended to discuss various historical periods, the comparison of which leads to interesting results concerning creativity. For example, the high Melting Pot Index in the Baltic republics during the Soviet period bears witness to both a policy (of industrialization and Russification) and the attractiveness of these republics to immigrants from other Soviet republics. Does this mean that Baltic societies during the Soviet period were more creative than during the democratic post-Soviet period when immigration was replaced by emigration? Far from it. Bearing this in mind, the Melting Pot Index could be extended by taking into account second- or third-generation immigrants. The insularity of the Tatar, Karim and Jewish communities allows one to include immigrants who came 600 years ago.

The return of the Vilnius region to Lithuania in 1939 added to the Lithuanian melting pot several hundred thousand Poles and Jews who neither came nor went; instead, the Vilnius region "came" to them. Similarly, the collapse of the Soviet Union turned thirty or forty million Russian-speakers into emigrants after the edges of the empire had drifted to other states with other state languages. Comparing the inhabitants of the Vilnius region to whom Lithuania "came" with the subsequent immigrants who came to Lithuania in the Soviet time, the latter have more readily integrated into Lithuanian society than the former. It is the paradox of "roots": the immigrants are ingredients who are more readily boiled than the local people, the roots of whom have sunk into the cultural media including language. The attitude that changing environments and shifting regions must regard the traditions (roots) of local communities. A locality that seeks to keep its cultural roots and is thus contrary in principle to nation being formed ${ }^{4}$, is correct in its naïve way to resist the tendencies of melting pot: the advancing central culture is an ingredient of the local melting pot, but the local, peripheral culture is not an ingredient in the central culture.

This change in melting pot perspectives (the pots in a pot) lets us view the very concept of a melting pot (and pots) from another angle so as to harmonize it with the concept of regional culture. Nevertheless, the main question that arises here is as follows: how are the phenomena of melting pot, regionality and locality to be connected with the creativity of a society? My assumption is as follows: creativity is nourished not by an integrated, trivialized and homogenised society but by the clashes between its centre and peripheries. If so, then creative society should foster cultural and national differences rather than eliminate them. Consequently, the idea of a melting pot and its index is not as well defined index of creativity. Instead of it, we are faced with the prospect of another index, namely one of regionality. It would express local authenticity and local resistance to the homogeneity of central culture.

\section{Integrative Creativity Indices}

In general, the variety and diversity which had so troubled Plato (1992), who had criticised democratic society, are inseparable from the creativity that stimulates innovations and economic growth, i.e. leads a society to a high standard of living. It is likely that the variety of nations and traditions presupposes a melting pot of ideas and creative products. Nevertheless, we face here the danger of society's disintegration which had also frightened Plato: a society should be of a size which accords with uniformity. Whereas all of the creativity indices considered bear witness to the variety and diversity of a society. The creativity of a society is nourished not only by the society's variety but also by its identity,

\footnotetext{
${ }^{3}$ In Lithuania, there is a saying: if you want to destroy a city, drive the Jews out of it.

${ }^{4}$ Comp. B. Anderson 1991.
} 
which is inseparable from the traditions that have been handed-down over generations. Identity is the vessel of creativity: upon losing its container, creativity becomes destructive and a threat to the entire society.

That is why R. Florida's $(2002,2012)$ integrative indices are paradoxical: integration appeals to a society's homogeneity whereas the component indices appeal to society's variety or even disunity. The First or Minor Integrative Index has been named accordingly: the Integrative Index of Variety. It combines the Gay, Bohemian and Melting Pot Indices. The following question arises: How does this index express the creativity of society in expressing social variety? It was mentioned that at least two of the indices (Gay and Melting Pot) are very dubious as creativity indices. These dubious indices do not become more reliable upon being combined, quite the contrary. Another problem is their computability. The Bohemian and the Gay Index are hardly computable because of the unclear borders of the regions they are meant to define. That is why the Minor Integrative Index is even less computable.

Another integrative index is the Major Integrative Creativity Index that combines all of the indices mentioned by R. Florida (2002, 2012): the Bohemian, High Tech, Innovation, Talent, Gay, and Melting Pot Indices. In this case, both of the flaws characteristic of the Minor Creativity Index persist. Indeed, they even increase because of the greater scope of this integrative index. In the case of different societies and different regions, this Index may give very different results because of the varying factors affecting its components. For example, the Melting Pot Index is very low in the eastern half of the European Union (namely, Central Europe). As mentioned, it is not necessarily connected with creativity, but possibly with the political and economic situation. Whereas the Talent Index is very high in Lithuania but this shows not so much the society's high creativity but rather the devaluation of university education. An index is the more empirical the smaller the region and the narrower the index's content, i.e. the less it is integrative.

\section{Conclusions}

It is impossible to count gays not only because of the fact that some such individuals are not self-defined as gays. The problem of bisexuality follows also from the fact that "gay" first of all is a cultural, social and ethical category, but not a physical one. The overlapping and changing of social environment are the attributes of a creative society: creativity is nourished by migrating ideas that fill up with unique content after being in different identity regions. Although it is impossible to measure gayness, it does indirectly reflect the diversity of society and nourishes its creativity.

The Talent Index expresses something fundamentally contradictory to talent, that is, an orientation towards the average consumer's taste. We face a contradiction in the case of the Talent Index: as the Talent Index rises, the actual talent of a society decreases and loses value. It is impossible to measure talent which is unique. After becoming measurable i.e. mass, it loses its significance. In summary, this index is easily measurable but is dubious as a creativity index.

Creativity is nourished not by an integrated, trivialized and homogenised society but by the clashes between its centre and peripheries. As result, creative society should foster cultural and national differences rather than eliminate them. Consequently, the idea of a melting pot and its index is not as well defined index of creativity. Instead of it, we are faced with the prospect of another index, namely one of regionality. It would express local authenticity and local resistance to the homogeneity of central culture.

In the case of the integrative indices, the biggest problem is not how to sum several indices but on what basis they should be summed, i.e. whether they can be summed in principle and what does such an integrative index express. Both the Minor and Major 
Integrative Indices lose their empirical value not so much in being difficult to measure as in appealing to what is nonempirical, i.e. to historical consciousness, worldviews, religious beliefs, and the cultivation of tradition. A question arises as follows: Does the transgression of empirical boundaries make for a less scientific investigation? From what has been said follows the contrary conclusion: the treatment of the empirical domain as a limited domain to be transgressed shows the limits of this method (in this case, the empirical method). This is possible by looking at it from a removed perspective. Here the removed perspective for sociological and economic research is philosophy. The merit accorded to R. Florida that he has grounded creativity discourse in a scientific way should not be associated with his orientation to empirical methods of accounting for creativity. Rather, on the contrary: his approach is scientific in as much as it allows the transcending of these methods, i.e. by establishing their limitations.

\section{References}

Adomaitytè, G., Žilinskaitè, V., Sederevičiūtė-Pačiauskienè, Ž., Valantinaitè, I., \& Navickienè, V. (2018). Shift of Creativity Concepts: From Mysticism to Modern Approach. Filosofija. Sociologija, 29(3), 203-210.

Al-Sudairi, M., \& Haj Bakry, S. (2014). Knowledge issues in the global innovation index: Assessment of the state of Saudi Arabia versus countries with distinct development. Innovation, 16(2), 176-183.

Anderson, B. (1991). Imagined communities: reflections on the origin and spread of nationalism. London: Verso.

Arndt, J., Greenberg, J., Solomon, S., Pyszczynski, T., \& Schimel, J. (1999). Creativity and terror management: Evidence that creative activity increases guilt and social projection following mortality salience. Journal of personality and social psychology, 77(1), 19-32.

Barevičiūtè, J. (2014). Pagrindiniai kūrybiškumo ir kūrybingumo aspektai šiuolaikiniuose humanitariniuose bei socialiniuose moksluose [The aspects of creativity and creativeness in contemporary humanities and social sciences]. Filosofija. Sociologija, 25(1), 19-28.

Butler, J. (1990). Gender trouble. Routledge: Chapman and Hall.

Carroll, E. A., Latulipe, C., Fung, R., \& Terry, M. (2009, October). Creativity factor evaluation: towards a standardized survey metric for creativity support. In Proceedings of the seventh ACM conference on Creativity and cognition (pp. 127-136). ACM.

Çetindamar, D., \& Günsel, A. (2012). Measuring the creativity of a city: a proposal and an application. European Planning Studies, 20(8), 1301-1318.

Chang, J. J., Hung, K. P., \& Lin, M. J. J. (2014). Knowledge creation and new product performance: the role of creativity. $R \& D$ Management, 44(2), 107-123.

Cherry, E., \& Latulipe, C. (2014). Quantifying the creativity support of digital tools through the creativity support index. ACM Transactions on Computer-Human Interaction (TOCHI), 21(4), 1-25.

Cooke, P. \& L. Lazzeretti (eds.) (2008). Creative cities, cultural clusters and local economic development. Cheltenham: Edward Elgar.

Florida, R. (2002). The Rise of Creative Class. New York: Basic Books.

Florida, R. (2005). Cities and the creative class. New York, London: Routledge.

Florida, R. (2012). The rise of the creative class revisited. New York: Basic Books.

Florida, R., Tinagli, I. (2004). Europe in the creative age. Europe: Demos.

$\mathrm{Fu}, \mathrm{X}$. (2008). Foreign direct investment, absorptive capacity and regional innovation capabilities: evidence from China. Oxford Development Studies, 36(1), 89-110.

Fürst, G., Ghisletta, P., \& Lubart, T. (2012). The creative process in visual art: A longitudinal multivariate study. Creativity Research Journal, 24(4), 283-295. 
Gadamer, H.-G. (1975). Wahrheit und Methode. Tübingen: Mohr (Paul Siebeck).

Hong Kong. (2004). The home affairs bureau of the Hongkong special administrative region government. Study on creativity index. Hong Kong: Hong Kong University of Cultural Policy Research Center.

Howkins, J. (2007). The Creative Economy. London: Penguin.

Huiyuhl, Y. I. (2018). Constitutive and depictive creativities in philosophy and critical thinking. Creativity Studies, 11(1), 24-40.

Hunter, S. T., Bedell, K. E., \& Mumford, M. D. (2007). Climate for creativity: A quantitative review. Creativity research journal, 19(1), 69-90.

Yasmin, M., \& Sohail, A. (2018). A creative alliance between learner autonomy and English language learning: Pakistani University teachers' beliefs. Creativity Studies, 11(1), 1-9.

Irigaray, L. (1977). Ce sexe qui n'en est pas un. Paris: Les Editions de Minuit.

Juzefovič, A. (2015). Creativity and aesthetic applied to ecological education. Creativity Studies, 8(1), 12-24.

Kačerauskas, T. (2016). Creativity Management: Towards Soft Control. Economics \& Sociology, 9(4), 336.-343. DOI: 10.14254/2071-789X.2016/9-4/21

Kaufman, J. C., Cole, J. C., \& Baer, J. (2009). The construct of creativity: Structural model for self-reported creativity ratings. The Journal of Creative Behavior, 43(2), 119-134.

Kornilova, T. V., \& Kornilov, S. A. (2012). Is it possible to create a model of creativity without psychology of creativity?. Psikhologicheskii zhurnal, 33 (6), 76-83.

Krätke, S. (2003). Global media cities in a world-wide urban network. European Planning Studies, 11(6), 605-628.

Krätke, S. (2010). 'Creative cities' and the rise of the dealer class: A critique of Richard Florida's approach to urban theory. International Journal of Urban and Regional Research, 34(4), 835-853.

Liang, C., Hsu, Y., Chang, C. C., \& Lin, L. J. (2013). In search of an index of imagination for virtual experience designers. International Journal of Technology and Design Education, 23(4), 1037-1046.

Manta, A. (2018). Demystifying creativity: an assemblage perspective towards artistic creativity. Creativity Studies, 11(1), 85-101.

Martinaityte, E., \& Kregzdaite, R. (2015). The factors of creative industries development in nowadays stage. Economics \& Sociology, 8(1), 55. DOI: 10.14254/2071- 789X.2015/8$1 / 5$

Murphy, J. W., \& Schlaerth, C. A. (2015). Tourism at the museum and the lifeworld. Creativity Studies, 8(2), 115-123.

Paek, K. M. (2018). Creative engagement on ecological issues: studio work experience in a context of interdisciplinary learnin. Creativity Studies, 11(1), 41-55.

Piskunova, L., Starostova, L., \& Yankov, I. (2018). The architecture of constructivism: the creative transformation of aesthetic codes and narratives. Creativity Studies, 11(1), 56-69.

Plato. (1992). The Republic. Indianapolis: Hackett publishing company.

Portes, A. (1998). Social capital: Its origins and applications in modern sociology. Annual review of sociology, 24(1), 1-24.

Power, D., Scott, A. J. (eds.). (2004). Cultural industries and the production of culture. London: Routledge.

Pruskus, V. (2015). Kūrybingumo panaudojimo gerinant aplinkos kokybę etiniai ir socialiniai kultūriniai aspektai. Filosofija. Sociologija, 26(3), 201-209.

Putnam, R. D. (2002). Bowling alone. The collapse and revival of American community. New York, London, Toronto, Sydney, Singapore: Simon \& Schuster.

Rabazauskaite, V. (2015). Revitalisation of public spaces in the context of creative tourism. Creativity Studies, 8(2), 124-133. 
Rank, O. (1989 (1929)). Truth and reality. New York: Knof.

Reiter-Palmon, R., Illies, M. Y., Kobe Cross, L., Buboltz, C., \& Nimps, T. (2009). Creativity and domain specificity: The effect of task type on multiple indexes of creative problemsolving. Psychology of Aesthetics, Creativity, and the Arts, 3(2), 73-80.

Runco, M. A. (2004). Creativity. Annual Review of Psychology, 55, 657-687.

Runco, M. A., Illies, J. J., \& Eisenman, R. (2005). Creativity, originality, and appropriateness: What do explicit instructions tell us about their relationships?. The Journal of Creative Behavior, 39(2), 137-148.

Scott, A. J. (2000). The cultural economy of cities: essays on the geography of imageproducing industries. New York and London: Sage

Shanghai creative industries Center. (2006). Shanghai creative industries development report. Shanghai: Shanghai Science and Technology Literature Publishing House.

Soler, J. M. (2007). A rational indicator of scientific creativity. Journal of Informetrics, 1(2), 123-130.

Squalli, J., \& Wilson, K. (2014). Intelligence, creativity, and innovation. Intelligence, 46, 250-257.

Staniulytè, E. (2017). Kūrybinis miestas: nuo teorinès koncepcijos prie praktinio igyvendinimo. Filosofija. Sociologija, 28(1), 84-88.

Torrance, E. P. (1966). The Torrance Tests of Creative Thinking. Lexington: Personnel Press.

Vabalaite, R. M. (2017). Activity and passivity in the creation of art: Heidegger and later philosophers. Filosifija sociologija., 28(1), 3-10.

Valatka, V. (2016). Creative visualizations of ethical principles of Ancient Greek Cynicism and their significance to modern society. Filosifija sociologija., 27(1), 61-69.

Weinstein, E. C., Clark, Z., DiBartolomeo, D. J., \& Davis, K. (2014). A decline in creativity? It depends on the domain. Creativity research journal, 26(2), 174-184.

Xue, G. (2013, July). The modeling of China city creativity index and an empirical research. In Management Science and Engineering (ICMSE), 2013 International Conference on (pp. 2289-2295). IEEE.

Zolfani, S. H., Maknoon, R., \& Juzefovič, A. (2017). Leadership, music and creative society: A philosophical analysis of possible future. Filosifija sociologija., 28(1), 20-28. 